\title{
Cytotoxic properties of the anthraquinone derivatives isolated from the roots of Rubia philippinensis
}

Vivek K. Bajpai ${ }^{1}$, Md Badrul Alam², ${ }^{2,}$ Khong Trong Quan ${ }^{4}$, Hee-Jeong Choi², Hongyan An², Mi-Kyoung Ju², Sang-Han Lee ${ }^{2,3^{*}}$, Yun Suk Huh ${ }^{5}$, Young-Kyu Han ${ }^{{ }^{*}}$ and MinKyun Na ${ }^{4^{*}}$

\begin{abstract}
Background: Cancer is one of the most frequently occurring diseases and is the second leading cause of death worldwide. In this study, anthraquinone derivatives (Compounds 1-5) were evaluated for their anti-cancer potential against various skin and breast cancer cell lines to assess whether these anthraquinone derivatives may serve as a lead for the augmentation of anti-cancer drug.

Methods: Anthraquinone derivatives, 2-methyl-1,3,6-trihydroxy-9,10-anthraquinone-3-O-(6'-O-acetyl)-a-rhamnosyl( $\rightarrow$ - 2)$\beta$-glucoside (Comp 1), 2-methyl-1,3,6-trihydroxy-9,10-anthraquinone (Comp 2), and alizarin (Comp 3) were isolated from the dichloromethane fraction of the roots of Rubia philippinensis., whereas ethyl acetate fraction yielded xanthopurpurin (Comp 4) and lucidin- $\omega$-methyl ether (Comp 5). Structures of all the isolated compounds were determined by spectral data analysis. All isolated compounds (Comp 1-5) were assessed for cytotoxicity by the 3-(4,5-dimethylthiazol-2-yl)-2,5diphenyltetrazolium bromide (MTT) assay against four different cancer cell lines, i.e. human melanoma (SK-MEL-5), murine melanoma (B16F10), and human breast adenocarcinoma (MCF7 and MDA-MB-231).

Results: Significant activity of the compounds 4 and 5 was observed against the breast cancer cell line MDA-MB-231 with $I_{50}$ values of $14.65 \pm 1.45$ and $13.03 \pm 0.33 \mu \mathrm{M}$, respectively. Encouragingly, $I_{50}$ values of $67.89 \pm 1.02$ and $79.01 \pm$ $0.03 \mu \mathrm{M}$ against normal kidney epithelial cells (MDCK) were also obtained for compounds 4 and 5 , respectively, which indicated very low toxicity and favorable selectivity indices for compounds 4 and 5 in the range of 1.85 to 3.95 and 2 . 11 to 6.06 against skin cancer cell lines (SK-MEL-5, and B16F10), and breast cancer cell lines (MCF7 and MDA-MB-231), respectively.

Conclusion: Our results suggested that the compounds 4 (xanthopurpurin) and 5 (lucidin- $\omega$-methyl ether) showed high selective toxicity towards breast cancer cells at lower concentrations without showing toxicity towards normal cells, thus could be of potential as new lead molecules in cancer treatment.
\end{abstract}

Keywords: Rubia philippinensis, Anthraquinone, Cytotoxicity, Breast cancer, Skin cancer

\section{Background}

Cancer is one of the most frequently occurring diseases and is the second leading cause of death worldwide, while chemotherapy is most extensively used among a wide range

\footnotetext{
*Correspondence: sang@knu.ac.kr; ykenergy@dongguk.edu; mkna@cnu.ac.kr ${ }^{2}$ Department of Food Science and Biotechnology, Graduate School, Kyungpook National University, Daegu 41566, Republic of Korea

'Department of Energy and Materials Engineering, Dongguk University-Seoul, Seoul 04620, Republic of Korea

${ }^{4}$ College of Pharmacy, Chungnam National University, Daejeon 34134 Republic of Korea

Full list of author information is available at the end of the article
}

of anti-cancer therapies, and its high toxicity, being expensive as well as activating alternative cell signaling pathways are limiting its applications [1]. For centuries to date, being safe, low cost and easily accessible, medicinal herbs are viewed as the main sources of new drugs to treat cancer worldwide while various pharmacological studies continue to validate their uses [1]. Moreover, herbal medicines are widely assumed in complementary and alternative medicine especially in cancer patients with poor socioeconomic condition. Mounting evidences suggest that plants possessing anticancer properties, such as Soymida fembrifuga

(c) The Author(s). 2018 Open Access This article is distributed under the terms of the Creative Commons Attribution 4.0 International License (http://creativecommons.org/licenses/by/4.0/), which permits unrestricted use, distribution, and reproduction in any medium, provided you give appropriate credit to the original author(s) and the source, provide a link to the Creative Commons license, and indicate if changes were made. The Creative Commons Public Domain Dedication waiver (http://creativecommons.org/publicdomain/zero/1.0/) applies to the data made available in this article, unless otherwise stated. 
(Miliaceae), Tinospora cordifolia (Menispermaceae), Lavandula bipinnata (Lamiaceae), Helicteres isora (Sterculiaceae), Urtica membranacea (Urticaceae), Artemesia monosperma (Asteraceae), and Origanum dayi post (Labiatae) etc., are the source of alternative medicine for cancer therapy in various regions of the globe [2-4]. However, a large number of plant species remain to be screened for their therapeutic potential; consequently, they can be used as a continual source of new medicines for present and future health problems of humans, including cancer.

Rubia philippinensis is a rambling and low climbing perennial herb that grows in the Southern part of Vietnam. Local communities have long utilized this medicinal plant to treat ordinary ailments such as wounds, inflammation, and skin infections. Previous investigations of the species have resulted in the purification of arborinane triterpenoids, which show promising effects on the prevention and treatment of atherosclerosis [5]. Additionally, rubiarbonone $\mathrm{C}$, a popular chemical entity isolated from $R$. philippinensis, has been shown to inhibit abnormal proliferation and migration of vascular smooth muscle cells, which plays an important role in the pathophysiology of atherosclerosis. The mechanism by which rubiarbonone $\mathrm{C}$ regulates vascular remodeling was further clarified through focal adhesion kinase (FAK), MAPK, and STAT3 Tyr705 [6]. In searching for bioactive components from $R$. philippinensis, in this study, derivatives of anthraquinone were isolated as the major compounds.

Anthraquinones possessing three benzene rings represent a class of compounds belonging to quinone family. The divergence of the anthraquinone molecules relies on the nature and the setting of the substituents. Anthraquinones display a number of biological functions, including laxative [7], diuretic [8], phytoestrogen [9], anti-platelet [10], anti-fungal [11], anti-viral [12], and anti-cancer properties [13]. Moreover, they have a significant industrial potential of being used as textile dyes, food colorants and bugs repellents.

As a part of continuous attempts to probe the potential nature-derived drug templates for the treatment of cancer $[5,14]$, the current study delineates the isolation and characterization of five anthraquinone derivatives (compound 1-5) from $R$. philippinensis. These compounds were evaluated for their anti-cancer potential against various skin cancer cells (SK-MEL-5 and B16F10) and breast cancer cells (MCF7 and MDA-MB-231) to assess whether these anthraquinone derivatives may serve as a lead for the development of anti-cancer drugs.

\section{Methods}

\section{Plant materials}

Root samples of Rubia philippinensis were procured from Bidoup-Nui Ba National Park, Lamdong province, Vietnam and identified by the expert Dr. Phuong Thien Thuong at the Department of Pharmaceutical Analysis and Herbal Standardization, NIMM, Hanoi, Vietnam. An authenticated root voucher sample was deposited at the laboratory of the NIMM (VDL20140801) and at the Pharmacognosy Laboratory, College of Pharmacy, Chungnam National University (CNU1409), Daejeon, Korea.

\section{Extraction, isolation, and characterization of anthraquinone derivatives}

Anthraquinones were isolated from the root samples of $R$. philippinensis by chromatographic techniques. In brief, the ethanol extract of $R$. philippinensis $(150 \mathrm{~g})$ was suspended in $\mathrm{H}_{2} \mathrm{O}(1.5 \mathrm{~L})$ and sequentially partitioned with $\mathrm{CH}_{2} \mathrm{Cl}_{2}(2 \mathrm{~L} \times 3)$ and EtOAc $(2 \mathrm{~L} \times 3)$ to yield the $\mathrm{CH}_{2} \mathrm{Cl}_{2}$ and EtOAc extracts. The $\mathrm{CH}_{2} \mathrm{Cl}_{2}$-soluble fraction $(50 \mathrm{~g})$ was loaded into silica gel VLC and eluted with $n$-hexane-EtOAc (20:1, 10:1, 5:1, 3:1, 2:1) and $\mathrm{CHCl}_{3}-\mathrm{MeOH}$ $(8: 1)$ to afford six fractions (D-1 $\rightarrow$ D-6). Fraction D-4 $(6.1 \mathrm{~g})$ was divided into 10 sub-fractions (D-4-1 $\rightarrow$ D-4-10) using MPLC with a step-wise gradient of Acetone- $\mathrm{H}_{2} \mathrm{O}$ (60:40, 72:28, 75:25, 95:5, 100:0, each 1.5 L). Xanthopurpurin $(4)\left(t_{\mathrm{R}} 33.5 \mathrm{~min}, 28 \mathrm{mg}\right)$ and lucidin- $\omega$-methyl ether (5) ( $t_{\mathrm{R}} 36.0 \mathrm{~min}, 31 \mathrm{mg}$ ) were obtained from D-4-4 (320 mg) by HPLC eluting with $\mathrm{MeCN}-\mathrm{H}_{2} \mathrm{O}$ (54.5:45.5, $4 \mathrm{~mL} / \mathrm{min}$, UV $360 \mathrm{~nm}$ ). The EtOAc fraction $(14.0 \mathrm{~g})$ was subjected to silica gel VLC and eluted with $n$-hexane/ EtOAc/MeOH (2:1:0.2) and $\mathrm{CHCl}_{3}-\mathrm{MeOH}$ (8:1, 5:1, 3:1, $0: 1)$ to yield five fractions (EA-1 $\rightarrow$ EA-5). Eight sub-fractions (EA-1-1 $\rightarrow$ EA-1-8) were collected from fraction EA-1 (1.8 g) by utilizing MPLC, eluting with $\mathrm{MeOH}-\mathrm{H}_{2} \mathrm{O}$ (10:90, 50:50, 67:33, 80:20, 100:0, each $500 \mathrm{~mL}$ ). Alizarin (3) ( $\left.t_{\mathrm{R}} 44.0 \mathrm{~min}, 2 \mathrm{mg}\right)$ was isolated from EA-1-5 (100 mg) by HPLC eluting with $\mathrm{MeCN}-\mathrm{H}_{2} \mathrm{O}$ (44.5:55.5, $4 \mathrm{~mL} / \mathrm{min}$, UV $360 \mathrm{~nm})$. Two sub-fractions EA-1-6 and EA-1-7 were combined (EA-1-6,7; $500 \mathrm{mg}$ ), then purified one more time by MPLC, eluted with Acetone- $\mathrm{H}_{2} \mathrm{O}(40: 60,60: 40,100: 0$, each $500 \mathrm{~mL})$ to afford 2-methyl-1,3,6-trihydroxy-9,10-anthraquinone (2) as orange crystals (200 mg). Fraction EA-4 (2.6 g) was separated by MPLC applying mixtures of solvent $\mathrm{MeOH}-\mathrm{H}_{2} \mathrm{O}$ (23:77, 37:63, 47:53, 52:48, 60:40, 67:33, 100:0, each $400 \mathrm{~mL}$ ) to yield 11 sub-fractions (EA-4-1 $\rightarrow$ EA-4-11). 2-methyl-1,3,6-trihydroxy-9,10-anthraquinone3 -O-(6'-O-acetyl)- $\alpha$-rhamnosyl $(1 \rightarrow 2)$ - $\beta$-glucoside $(\mathbf{1})\left(t_{\mathrm{R}}\right.$ $40 \mathrm{~min}, 800 \mathrm{mg}$ ) was purified from sub-fractions EA-4-8 (706 mg) and EA-4-9 (410 mg) by HPLC utilizing $\mathrm{MeOH}-\mathrm{H}_{2} \mathrm{O}$ (65:35, $6 \mathrm{~mL} / \mathrm{min}$, UV $\left.254 \mathrm{~nm}\right)$.

2-methyl-1,3,6-trihydroxy-9,10-anthraquinone-3-O-(6'-Oacetyl)- $\alpha$-rhamnosyl $(1 \rightarrow 2)$ - $\beta$-glucoside $(\mathbf{1})$ : yellow powder, ${ }^{1} \mathrm{H}$ NMR (300 MHz, DMSO- $\left.d_{6}\right): \delta_{\mathrm{H}} 13.28(1 \mathrm{H}, \mathrm{s}, \mathrm{OH}-1)$, $8.08(1 \mathrm{H}, \mathrm{d}, J=8.4 \mathrm{~Hz}, \mathrm{H}-8), 7.45(1 \mathrm{H}, \mathrm{d}, J=2.4 \mathrm{~Hz}, \mathrm{H}-5)$, $7.40(1 \mathrm{H}, \mathrm{s}, \mathrm{H}-4), 7.20(1 \mathrm{H}, \mathrm{dd}, J=8.4,2.4 \mathrm{~Hz}, \mathrm{H}-7), 5.45$ $\left(1 \mathrm{H}, \mathrm{d}, J=6.9 \mathrm{~Hz}, \mathrm{Glu}-\mathrm{H}-1^{\prime}\right), 5.28(1 \mathrm{H}, \mathrm{d}, J=0.9 \mathrm{~Hz}$, Rha-H-1"), 2.15 (3H, s, $\left.\mathrm{CH}_{3}-2\right), 1.93$ (3H, s, OAc-6'), 1.09 
$\left(3 \mathrm{H}, \mathrm{d}, J=6.3 \mathrm{~Hz}\right.$, Rha- $\left.\mathrm{CH}_{3}-6 "\right) .{ }^{13} \mathrm{C}$ NMR $(150 \mathrm{MHz}$, DMSO- $\left.d_{6}\right) \delta_{\mathrm{C}}$ Aglycone: 164.2 (C-1), 120.5 (C-2), 160.0 (C-3), 105.2 (C-4), 135.4 (C-4a), 112.8 (C-5), 161.3 (C-6), 121.6 (C-7), 129.7 (C-8), 124.1 (C-8a), 186.3 (C-9), 110.7 (C-9a), 181.8 (C-10), 131.9 (C-10a), $8.7\left(\mathrm{CH}_{3}-2\right)$. Glucose: 97.3 (C-1'), 76.3 (C-2'), 77.0 (C-3'), 70.0 (C-4'), 74.0 (C-5'), 63.3 (C-6'), 170.3 (OAc-6'), 20.4 (OAc-6"). Rhamnose: 100.2 (C-1"), 70.3 (C-2"), 70.5 (C-3"), 72.0 (C-4"), 68.5 (C-5"), 18.1 (C-6").

2-methyl-1,3,6-trihydroxy-9,10-anthraquinone (2): orange crystal, ${ }^{1} \mathrm{H}$ NMR $\left(300 \mathrm{MHz}, \mathrm{DMSO}-d_{6}\right): \delta_{\mathrm{H}} 13.31(1 \mathrm{H}, \mathrm{s}$, OH-1), $8.05(1 \mathrm{H}, \mathrm{d}, J=8.4 \mathrm{~Hz}, \mathrm{H}-8), 7.43(1 \mathrm{H}, \mathrm{d}, J=2.4 \mathrm{~Hz}$, H-5), 7.20 (1H, s, H-4), $7.20(1 \mathrm{H}, \mathrm{dd}, J=8.4,2.4 \mathrm{~Hz}, \mathrm{H}-7)$, $2.05\left(3 \mathrm{H}, \mathrm{s}, \mathrm{CH}_{3}-2\right) .{ }^{13} \mathrm{C}$ NMR $\left(75 \mathrm{MHz}, \mathrm{DMSO}-d_{6}\right) \delta_{\mathrm{C}}$ 162.3 (C-1), 117.4 (C-2), 163.1 (C-3), 107.1 (C-4), 135.2 (C-4a), 112.5 (C-5), 162.1 (C-6), 121.3 (C-7), 129.4 (C-8), 124.7 (C-8a), 185.8 (C-9), 108.6 (C-9a), 182.0 (C-10), 131.8 (C-10a), $8.1\left(\mathrm{CH}_{3}-2\right)$.

Alizarin (3): brownish red powder, ${ }^{1} \mathrm{H}$ NMR $(300 \mathrm{MHz}$, DMSO- $\left.d_{6}\right) \delta_{\mathrm{H}} 7.51(1 \mathrm{H}, \mathrm{d}, J=8.1, \mathrm{H}-4), 7.18(1 \mathrm{H}, \mathrm{d}, J=8.1$, $\mathrm{H}-3) .{ }^{13} \mathrm{C}$ NMR $\left(150 \mathrm{MHz}, \mathrm{DMSO}-d_{6}\right) \delta_{\mathrm{C}} 151.0(\mathrm{C}-1)$, 153.3 (C-2), 120.8 (C-3), 121.3 (C-4), 126.5 (C-5), 134.0 (C-6), 135.1 (C-7), 126.7 (C-8), 188.8 (C-9), 180.5 (C-10), 123.5 (C-4a), 132.9 (C-10a), 133.7 (C-8a), 116.2 (C-9a).

Xanthopurpurin (4): orange powder, ${ }^{1} \mathrm{H}$ NMR $(300 \mathrm{MHz}$, DMSO- $\left.d_{6}\right) \delta_{\mathrm{H}} 7.79(1 \mathrm{H}, \mathrm{d}, J=2.1, \mathrm{H}-4), 7.27(1 \mathrm{H}, \mathrm{d}, J=2.1$, H-3). ${ }^{13} \mathrm{C}$ NMR (75 MHz, DMSO- $\left.d_{6}\right) \delta_{\mathrm{C}} 164.7(\mathrm{C}-1), 107.6$ (C-2), 165.5 (C-3), 108.4 (C-4), 126.7 (C-5), 134.5 (C-6), 134.3 (C-7), 126.2 (C-8), 185.6 (C-9), 181.6 (C-10), 134.7 (C-4a), 132.7 (C-10a), 132.8 (C-8a), 109.1 (C-9a).

Lucidin- $\omega$-methyl ether (5): orange powder, ${ }^{1} \mathrm{H}$ NMR $\left(300 \mathrm{MHz}, \mathrm{CDCl}_{3}\right) \delta_{\mathrm{H}} 13.24(1 \mathrm{H}, \mathrm{s}, \mathrm{OH}-1), 4.89(2 \mathrm{H}, \mathrm{s}$, $\left.\mathrm{CH}_{2} \mathrm{OCH}_{3}-2\right), 3.55$ (3H, s, $\left.\mathrm{CH}_{2} \mathrm{OCH}_{3}-2\right) .{ }^{13} \mathrm{C} \mathrm{NMR}$ $\left(75 \mathrm{MHz}, \mathrm{CDCl}_{3}\right) \delta_{\mathrm{C}} 162.0(\mathrm{C}-1), 114.5(\mathrm{C}-2), 164.2(\mathrm{C}-3)$, 109.7 (C-4), 127.5 (C-5), 134.3 (C-6), 134.2 (C-7), 126.8 (C-8), 187.0 (C-9), 182.3 (C-10), 133.6 (C-4a), 134.2 (C-10a), 133.6 (C-8a), 109.9 (C-9a), $69.0\left(\mathrm{CH}_{2} \mathrm{OCH}_{3}-2\right)$, $59.5\left(\mathrm{CH}_{2} \mathrm{OCH}_{3}-2\right)$.

\section{Cell culture and cell viability assay}

The potential cytotoxicity of the isolated anthraquinone derivatives was studied against various cancer cell lines, including SK-MEL-5 (human melanoma), B16F10 (murine melanoma) MCF7 (human breast adenocarcinoma), and MDA-MB-231 (human breast adenocarcinoma) and the normal cell line MDCK (normal kidney epithelial) using the MTT assay [15]. All cell lines were cultured in DMEM medium supplemented with $10 \%$ foetal bovine serum (FBS) and streptomycin-penicillin (100 $\mu \mathrm{g} / \mathrm{ml}$ each; Hyclone) in a $5 \% \mathrm{CO}_{2}$ humidified incubator. An MTT assay was employed to determine the percentage of the viability of various cancer cells as well as MDCK cells. All cells were first cultured in 96-well plates $\left(1 \times 10^{5}\right.$ cells $/ \mathrm{mL}$ for all cancerous cells and $5 \times 10^{5}$ cells $/ \mathrm{mL}$ for MDCK cells) for $24 \mathrm{~h}$, and treated with indicated concentration of isolated compounds $(6.25-100 \mu \mathrm{M}$ for cancerous cells and 6.25-400 $\mu \mathrm{M}$ for MDCK cells). Various dilutions of stock culture were made in the culture medium to get the final concentration of the sample with a $0.1 \%$ of DMSO concentration, including the control. After $24 \mathrm{~h}$ incubation, MTT reagent was added to each well and the plate was incubated at $37^{\circ}$ $\mathrm{C}$ for $1 \mathrm{~h}$. After removing the medium, the plate was washed twice with $\mathrm{PBS}(\mathrm{pH}$ 7.4). The intracellular insoluble formazan was dissolved in 100\% DMSO. A microplate reader was used to measure the absorbance of each cell line at $570 \mathrm{~nm}$, and the percentage of cell viability was calculated. The absorbance value for the average of wells of cells treated with each test sample concentration was expressed as a percentage of this control and the $\mathrm{IC}_{50}$ values for each sample on each cell line were calculated. The anti-cancer drug oxaloplatin was used as a positive control.

\section{Statistical analysis}

All the results were presented as the mean \pm SD following the analysis of one-way ANOVA. A value of $p<0.05$ was recognized as significant for the differences. An SPSS version of Windows' (Chicago, Illinois, USA) was performed for all the analyses.

\section{Results \\ Identification and characterization of anthraquinone derivatives (Fig. 1)}

The ${ }^{1} \mathrm{H}$ NMR data of compound 1 displayed signals of the anthraquinone aglycone, including one aromatic singlet proton $\delta_{\mathrm{H}} 7.40(1 \mathrm{H}, \mathrm{s}, \mathrm{H}-4)$, one $\mathrm{ABX}$ ring system $\delta_{\mathrm{H}} 8.08$ $(1 \mathrm{H}, \mathrm{d}, J=8.4 \mathrm{~Hz}, \mathrm{H}-8), 7.45(1 \mathrm{H}, \mathrm{d}, J=2.4 \mathrm{~Hz}, \mathrm{H}-5), 7.20$ $(1 \mathrm{H}, \mathrm{dd}, J=8.4,2.4 \mathrm{~Hz}, \mathrm{H}-7)$, and one singlet methyl $\delta_{\mathrm{H}}$ 2.15. The glycosidic linkage, meanwhile, contained resonances of two anomeric protons of the sugar moiety at $\delta_{\mathrm{H}}$ 5.45 (glucose), $\delta_{\mathrm{H}} 5.28$ (rhamnose), one secondary methyl $\left(\delta_{\mathrm{H}} 1.09\right.$, rhamnose), and one acetyl group $\left(\delta_{\mathrm{H}} 1.93\right)$. The ${ }^{13} \mathrm{C}$ NMR data showed 14 signals of a typical anthraquinone, including two ketones $\left(\delta_{\mathrm{C}} 186.3,181.8\right)$, and resonances for glucose $\left(\delta_{C} 97.3,76.3,77.0,70.0,74.0,63.3\right)$, acetoxy $\left(\delta_{C} 170.3,20.4\right)$, and rhamnose $\left(\delta_{C} 100.2,70.3\right.$, $70.5,72.0,68.5,18.1)$ moieties. On the basis of NMR spectroscopic data analyses, the compound was identified as 2-methyl-1,3,6-trihydroxy-9,10-anthraquinone-3-O-(6'-O-acetyl)- $\alpha$-rhamnosyl $(1 \rightarrow 2)$ - $\beta$-glucoside.

Similar to compound 1, compound 2 also showed resonances of one aromatic singlet proton, one ABX ring system, and one singlet methyl at $\delta_{\mathrm{H}} 7.20(1 \mathrm{H}, \mathrm{s}, \mathrm{H}-4) ;\left[\delta_{\mathrm{H}}\right.$ $8.05(1 \mathrm{H}, \mathrm{d}, J=8.4 \mathrm{~Hz}, \mathrm{H}-8 ; 7.43(1 \mathrm{H}, \mathrm{d}, J=2.4 \mathrm{~Hz}, \mathrm{H}-5$; $7.20(1 \mathrm{H}, \mathrm{dd}, J=8.4,2.4 \mathrm{~Hz}, \mathrm{H}-7)]$; and $\delta_{\mathrm{H}} 2.05(3 \mathrm{H}, \mathrm{s}$, $\mathrm{CH}_{3}-2$ ), respectively in ${ }^{1} \mathrm{H}$ NMR spectrum. On the other hand, the skeleton of 14 carbon signals along with two ketonic carbonyls $\left(\delta_{\mathrm{C}} 185.8,182.0\right)$ and one methyl functionality $\left(\delta_{\mathrm{C}} 8.1\right)$ was representative of ${ }^{13} \mathrm{C}$ NMR data of an 
<smiles>CC(=O)OC[C@H]1O[C@@H](Oc2cc3c(c(O)c2C)C(=O)c2ccc(O)cc2C3=O)[C@H](C[C@H]2O[C@H](C)[C@@H](O)[C@H](O)[C@H]2O)[C@H](O)[C@@H]1O</smiles>

Compound 1<smiles>Cc1c(O)cc2c(c1O)C(=O)c1ccc(O)cc1C2=O</smiles>

Compound 2<smiles>O=C1c2ccccc2C(=O)c2c1ccc(O)c2O</smiles>

Compound 3<smiles>O=C1c2ccccc2C(=O)c2c(O)cc(O)cc21</smiles>

Compound 4<smiles>COCc1c(O)cc2c(c1O)C(=O)c1ccccc1C2=O</smiles>

Compound 5

Fig. 1 Chemical structures of anthraquinone derivatives, 2-methyl-1,3,6-trihydroxy-9,10-anthraquinone 3-O-(6'-O-acetyl)-a-rhamnosyl( $1 \rightarrow 2)-\beta$-glucoside (compound 1), 2-methyl-1,3,6-trihydroxy-9,10-anthraquinone (compound 2), alizarin (compound 3), xanthopurpurin (compound 4), and lucidin- $\omega$-methyl ether (compound 5) isolated from R. philippinensis

anthraquinone. The 1D NMR of compound 2 resemble closely to those of compound 1, except for the absence of signals belonging to sugar units. In comparison with reference values, compound 2 was determined as 2 methyl-1,3,6-trihydroxy-9,10-anthraquinone. Compound 3, 4 , and 5 are also anthraquinone derivatives and their structures were elucidated as alizarin, xanthopurpurin, and lucidin- $\omega$-methyl ether, respectively, based on the NMR data analysis. NMR data of all anthraquinone has been provided in Additional file 1: Figures S1-S5).

\section{Cytotoxicity of anthraquinone derivatives}

All compounds were tested for cytotoxicity by MTT assay on cell lines SK-MEL-5, B16F10, MCF7, MDA-MB-231, and MDCK cells as a normal cell line, which showed significant cytotoxicity (Table 1, Additional file 1: Figures
S6-S10). Our results showed that the $\mathrm{IC}_{50}$ values for cancer cell lines treated ranged from $48.68 \pm 0.10$ to 91.04 $\pm 1.88 \mu \mathrm{M}$ for compound $1 ; 46.75 \pm 1.39$ to $79.96 \pm 1.14$ $\mu \mathrm{M}$ for compound 2 ; $48.64 \pm 0.33$ to $98.79 \pm 2.10 \mu \mathrm{M}$ for compound 3, $14.65 \pm 1.45$ to $23.71 \pm 1.71 \mu \mathrm{M}$ for compound 4 , and $13.03 \pm 0.33$ to $42.79 \pm 1.32 \mu \mathrm{M}$ for compound 5. Regarding the normal cell line MDCK cells, the $\mathrm{IC}_{50}$ values were $192.34 \pm 0.49,168.76 \pm 0.61,199.32 \pm$ $1.88,67.89 \pm 1.02$ and $79.01 \pm 0.03 \mu \mathrm{M}$ for compounds 1 , $2,3,4$, and 5 , respectively. Interestingly, among all the compounds, compounds 4 and 5 showed strong cytotoxicity towards breast cancer cells (MCF7 and MDA-MB231) than skin cancer cells (SK-MEL-5 and B16F10) with $\mathrm{IC}_{50}$ value of $15.75 \pm 1.00$ and $24.10 \pm 1.06$ for MCF7 as well as $14.65 \pm 1.45$ and $13.03 \pm 0.33$ for MDA-MB-231, respectively.

Table 1 IC 50 values of anthraquinone derivatives (compound 1-5) on various skin cancer cells (SK-MEL5 and B16F10) and breast cancer cells (MCF7 and MBA-MD-231)

\begin{tabular}{llllll}
\hline Compounds & \multicolumn{1}{l}{$\mathrm{C}_{50}(\mu \mathrm{M})^{\mathrm{a}}$} & & & \\
\cline { 2 - 5 } & SK-MEL-5 & B16F10 & MCF7 & MDA-MB-231 & MDCK \\
\hline 1 & $91.04 \pm 1.88$ & $48.68 \pm 0.10$ & $65.48 \pm 1.10$ & $49.44 \pm 0.78$ & $192.34 \pm 0.49$ \\
2 & $46.75 \pm 1.39$ & $77.88 \pm 0.34$ & $79.96 \pm 1.14$ & $59.22 \pm 0.40$ & $168.76 \pm 0.61$ \\
3 & $53.08 \pm 0.30$ & $98.79 \pm 2.10$ & $49.17 \pm 0.85$ & $48.64 \pm 0.33$ & $199.32 \pm 1.88$ \\
4 & $21.35 \pm 0.99$ & $23.71 \pm 1.71$ & $15.75 \pm 1.00$ & $14.65 \pm 1.45$ & $67.89 \pm 1.02$ \\
5 & $42.79 \pm 1.32$ & $29.48 \pm 2.61$ & $24.10 \pm 1.06$ & $13.03 \pm 0.33$ & $79.01 \pm 0.03$ \\
Oxaloplatin & $14.25 \pm 1.02$ & $10.51 \pm 0.92$ & $8.59 \pm 1.22$ & $7.95 \pm 1.92$ & $24.02 \pm 1.04$ \\
\hline
\end{tabular}

${ }^{a}$ The values are mean \pm standard deviation. $\mathrm{IC}_{50}$ (concentration inhibiting 50\% growth). SK-MEL-5 (human melanoma); B16F10 (murine melanoma); MCF-7 (human breast adenocarcinoma); MDA-MB-231 (human breast adenocarcinoma), MDCK (normal kidney epithelial cells) 
In addition, compound 4 and 5 were more cytotoxic to MDA-MB-231 cancer cell line $\left(\mathrm{IC}_{50}=14.65 \pm 1.45\right.$ and $13.03 \pm 0.33 \mu \mathrm{M}$, respectively) than to normal cells $\left(\mathrm{IC}_{50}=\right.$ $67.89 \pm 1.02$ and $79.01 \pm 0.03 \mu \mathrm{M}$ (Table 1), respectively with their respective selectivity indices of 4.63 and 6.06 (Table 2).

Table 2 shows the selectivity indices of the isolated compounds tested against the various cancer cell lines and the non-tumor cell line (MDCK). In the current study, treatments with compound 4 and 5 afforded the highest selectivity indices in breast cancer cell than skin cancer cells. Compound 4 showed the selectivity indices as 4.31 and 4.63 whereas compound 5 showed 3.28 and 6.06 in MCF7 and MDA-MB-231 cells, respectively (Table 2 ).

\section{Discussion}

A number of natural compounds have been isolated from different plant sources which have shown enormous biological potential [16-19]. In this study, five anthraquinone derivatives, such as 2-methyl-1,3,6-trihydroxy-9,10anthraquinone $\quad 3-O-(6$ '-O-acetyl)- $\alpha$-rhamnosyl $(1 \rightarrow 2)-\beta$ glucoside (compound 1), 2-methyl-1,3,6-trihydroxy-9,10anthraquinone (compound 2), alizarin (compound 3), xanthopurpurin (compound 4), and lucidin- $\omega$-methyl ether (compound 5) were isolated from the root of $R$. philippinensis., and were characterized based on the spectral data analysis [16-19].

These anthraquinone derivatives showed significant anticancer potential as confirmed by their cytotoxicity effects against various cancer cell lines, such as cell lines SK-MEL-5, B16F10, MCF7, MDA-MB-231, including normal MDCK cell line. However, according to American National Center Institute, extract/compounds with $\mathrm{IC}_{50}$ values lower than $30 \mu \mathrm{M}$ against experimental cancer cell lines constitute promising anticancer agents for drug development [20]. Therefore, compound 4 and 5 showed $\mathrm{IC}_{50}$ values greater than $30 \mu \mathrm{M}$ against all cell lines tested, and were more cytotoxic to normal line to which the cancer cell lines. Moreover, among the testest compounds,

Table 2 Selectivity of the cytotoxicity of anthraquinone derivatives (compound 1-5) to various cancer cells as compared with MDCK cells

\begin{tabular}{lllll}
\hline Compounds & \multicolumn{1}{l}{$\mathrm{C}_{50}(\mu \mathrm{M})^{\mathrm{a}}$} & & & \\
\cline { 2 - 5 } & SK-MEL-5 & B16F10 & MCF7 & MDA-MB-231 \\
\hline 1 & 2.11 & 3.95 & 2.94 & 3.89 \\
2 & 3.61 & 2.17 & 2.11 & 2.85 \\
3 & 3.76 & 2.02 & 4.05 & 4.10 \\
4 & 3.18 & 2.86 & 4.31 & 4.63 \\
5 & 1.85 & 2.68 & 3.28 & 6.06 \\
\hline
\end{tabular}

a The selectivity index is the ratio of the $\mathrm{IC}_{50}$ values of the treatments on MDCK cells to those in the cancer cell lines. SK-MEL-5 (human melanoma); B16F10 (murine melanoma); MCF-7 (human breast adenocarcinoma); MDA-MB-231 (human breast adenocarcinoma) anthraquinone derivatives xanthopurpurin (compound 4), and lucidin- $\omega$-methyl ether (compound 5) showed highest selectivity indices in breast cancer cell than skin cancer cells.

Mounting evidences have considered that a value greater than or equals to 2.0 is an interesting selectivity index [21]. This value means that the compound is more than twice more cytotoxic to the cancer cell line as compared with the normal cell line [21]. These findings demonstrated that compound 4 and 5 can be considered promising lead molecules for the development of anticancer drugs, especially for breast cancer, because they provided indices value greater than 2 .

\section{Conclusions}

It is very important to consider natural compounds as a chemotherapeutic agent for cancer which have minimum or no side effects on normal body cells of patients. To achieve this goal among various ways, one of the way is by employing lower doses of drug at which drug shows highly potent activity as well as exhibits high degree of selectivity. In this study, we presented the cytotoxicity potential of five anthraquinone derivatives isolated from the roots of Rubia philippinensis. The results of in vitro studies demonstrate the ability of the compounds 4 (xanthopurpurin) and 5 (lucidin- $\omega$-methyl ether) for high selective toxicity at lower concentrations (Table 1) without showing toxicity towards normal cells, confirming that compounds 4 and 5 may have the potentiality to be developed as anticancer drugs, especially for breast cancer. Further research strategies should investigate cytotoxic potential of compound 4 and 5 against multifactorial drug-resistant cancers for their pharmaceutical formulations.

\section{Additional file}

Additional file 1: Supplementary data contain ten supplementary figures. Among them Figures S1-S5 represent proton and carbon NMR data of the isolated compounds, whereas Figures S6-S10 represent cytotoxic effects of isolated compounds (1-5) against MDCK, SK-MEL-5, B16F10, MCF7, and MDA-MB-231 cell lines. (DOC 899 kb)

\section{Abbreviations}

ANOVA: Analysis of variance; DMEM: Dulbecco"s Modified Eagle"s Medium; DMSO: Dimethyl sulfoxide; FAK: Focal adhesion kinase; FBS: Foetal bovine serum; HPLC: High-performance liquid chromatography; MAPK: Mitogenactivated protein kinase; MPLC: Medium pressure liquid chromatography; MTT: 3-(4,5-dimethylthiazol-2-yl)-2,5-diphenyltetrazolium bromide; NMR: Nuclear magnetic resonance; SD: Standard deviation; UV: Ultraviolet; VLC: Vacuum liquid chromatography

Acknowledgements

This study was supported by the research fund of Chungnam National University.

Availability of data and materials

All data in combined within the manuscript and additional files. 


\section{Authors' contributions}

Designed the experiments: VKB, MBA, KTQ, HJC. Performed the experiments: MBA, KTQ, HA, MKJ. Analyzed the data: VKB, MBA, SHL, YKH, MN. Conception and design, analysis and interpretation of data, and contribution of reagents/ materials/analysis tools: MKN, SHL. Manuscript preparation and revision: VKB, MBA, YKH, MN. All authors have approved the final draft of the manuscript.

\section{Ethics approval and consent to participate}

Not applicable. This study did not involve use of animal or human subjects. The cell line was purchased from American type tissue culture (ATCC).

\section{Consent for publication}

Not applicable.

\section{Competing interests}

The authors declare that they have no competing interests.

\section{Publisher's Note}

Springer Nature remains neutral with regard to jurisdictional claims in published maps and institutional affiliations.

\section{Author details}

'Department of Energy and Materials Engineering, Dongguk University-Seoul, Seoul 04620, Republic of Korea. ${ }^{2}$ Department of Food Science and Biotechnology, Graduate School, Kyungpook National University, Daegu 41566, Republic of Korea. ${ }^{3}$ Food and Bio-Industry Research Institute, Kyungpook National University, Daegu 41566, Republic of Korea. ${ }^{4}$ College of Pharmacy, Chungnam National University, Daejeon 34134, Republic of Korea. ${ }^{5}$ Department of Biological Engineering, Biohybrid Systems Research Center (BSRC), Inha University, 100 Inha-ro, Nam-gu, Incheon 22212, Republic of Korea.

Received: 15 March 2018 Accepted: 7 June 2018

Published online: 03 July 2018

\section{References}

1. El-Kashak WA, Osman SM, Gaara AH, El-Toumy SA, Mohamed TK, Brouard I, et al. Phenolic metabolites, biological activities, and isolated compounds of Terminalia muelleri extract. Pharm Biol. 2017;55:2277-84.

2. Graham JG, Quinn ML, Fabricant DS, Farnsworth NR. Plants used against cancer - an extension of the work of Jonathan Hartwell. J Ethnopharmacol. 2000;73:347-77.

3. Solowey E, Lichtenstein M, Sallon S, Paavilainen H, Solowey E, LorberboumGalaski H, et al. Evaluating medicinal plants for anticancer activity. Sci World J. 2014;2014:e721402.

4. Shaikh R, Pund M, Dawane A, lliyas S. Evolution of anticancer, antioxidant, and possible anti-inflammatory properties of selected medicinal plants used in Indian traditional medication. J Tradit Complement Med. 2014;4:253-7.

5. Quan KT, Park HS, Oh J, Park HB, Ferreira D, Myung CS, Na M, et al. Arborinane triterpenoids from Rubia philippinensis inhibit proliferation and migration of vascular smooth muscle cells induced by the platelet-derived growth factor. J Nat Prod. 2016;79:2559-69.

6. Park HS, Quan KT, Han JH, Jung SH, Lee DH, Jo E, et al. Rubiarbonone C inhibits platelet-derived growth factor-induced proliferation and migration of vascular smooth muscle cells through the focal adhesion kinase, MAPK and STAT3 Tyr705 signaling pathways. Br J Pharmacol. 2017;174:4140-54.

7. Sakulpanich A, Gritsanapan W. Determination of anthraquinone glycoside content in Cassia fistula leaf extracts for alternative source of laxative drug. Int J Biomed Pharm Sci. 2009;3:42-5.

8. Zhou XM, Chen QH. Biochemical study of Chinese rhubarb. XXII. Inhibitory effect of anthraquinone derivatives on Na+-K+-ATPase of the rabbit renal medulla and their diuretic action. Acta Pharm Sin. 1988;23:17-20.

9. Matsuda H, Shimoda H, Morikawa T, Yoshikawa M. Phytoestrogens from the roots of Polygonum cuspidatum (Polygonaceae): structurerequirement of hydroxyanthraquinones for estrogenic activity. Bioorg Med Lett. 2001;11:1839-42.

10. Aburjai TA. Anti-platelet stilbenes from aerial parts of Rheum palaestinum. Phytochemistry. 2000;55(5):407-10.

11. Agarwal SK, Singh SS, Verma S, Kumar S. Antifungal activity of anthraquinone derivatives from Rheum emodi. J Ethnopharmacol. 2000;72:43-6.
12. Semple SJ, Pyke SM, Reynolds GD, Flower RL. In vitro antiviral activity of the anthraquinone chrysophanic acid against poliovirus. Antivir Res. 2001;49:169-78.

13. Nemeikaite-Ceniene A, Sergediene E, Nivinskas H, Cenas N. Cytotoxicity of natural hydroxyanthraquinones: role of oxidative stress. J Biosci. 2002;57:822-7.

14. Alam MB, Bajpai VK, Lee J, Zhao P, Byeon JH, Ra JS, et al. Inhibition of melanogenesis by jineol from Scolopendra subspinipes mutilans via MAPkinase mediated MITF downregulation and the proteasomal degradation of tyrosinase. Sci Rep. 2017;7:e45858.

15. Bajpai VK, Alam MB, Quan KT, Kwon KR, Ju MK, Choi HJ, et al. Antioxidant efficacy and the upregulation of Nrf2-mediated HO-1 expression by (+)-lariciresinol, a lignan isolated from Rubia philippinensis, through the activation of p38. Sci Rep. 2017;7:e46035.

16. Itokawa H, Mihara K, Takeya K. Studies on a novel anthraquinone and its glycosides isolated from Rubia cordifolia and R. akane. Chem Pharm Bull. 1983;31:2353-8.

17. Berger Y, Castonguay A, Brassard P. Carbon-13 nuclear magnetic resonance studies of anthraquinones. Org Mag Reson. 1980;14:103-8.

18. Chung Ml, Jou SJ, Cheng TH, Lin CN. Antiplatelet constituents of Formosan Rubia akane. J Nat Prod. 1994;57:313-6.

19. Banthorpe DV, White JJ. Novel anthraquinones from undifferentiated cell cultures of Galium verum. Phytochemistry. 1995;38:107-11.

20. Badisa RB, Darling-Reed SF, Joseph P, Cooperwood JS, Latinwo LM, Goodman $\mathrm{CB}$, et al. Selective cytotoxic activities of two novel synthetic drugs on human breast carcinoma MCF-7 cells. Anticancer Res. 2009;29(8):2993-6.

21. de Oliveira PF, Alves JM, Damasceno JL, Machado Oliveira RA, Dias HJ, Miller Crotti AE, Tavares DC. Cytotoxicity screening of essential oils in cancer cell lines. Rev Bras Farmacogn. 2015;25(2):183-88.

\section{Ready to submit your research? Choose BMC and benefit from:}

- fast, convenient online submission

- thorough peer review by experienced researchers in your field

- rapid publication on acceptance

- support for research data, including large and complex data types

- gold Open Access which fosters wider collaboration and increased citations

- maximum visibility for your research: over $100 \mathrm{M}$ website views per year

At BMC, research is always in progress.

Learn more biomedcentral.com/submissions 